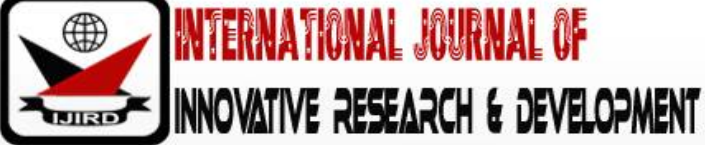

ISSN 2278 - 0211 (Online)

\section{Building Design Practice and Fire Codes for Buildlings in Nigeria (Issues, Effects and Solutions)}

Alhassan .I. David
Research Officer, Department of Building Research,
Nigerian Building and Road Research Institute (NBRRI), Nigeria
Victor Mlanga
Research Officer, Department of Building Research,
Nigerian Building and Road Research Institute (NBRRI), Nigeria
Musa Kyauta
Research Officer, Department of Building Research,
Nigerian Building and Road Research Institute (NBRRI), Nigeria
Panshak Dickson
Research Officer, Department of Building Research,
Nigerian Building and Road Research Institute (NBRRI), Nigeria

\begin{abstract}
:
Fire safety codes for buildings have been in existence over the years. The application of these codes in Architectural practice is questionable, due to the incessant collapse of buildings resulting from fire, which has lead to the loss of several lives and properties. The need for adequate implementation of these codes in the field of building design and construction cannot be overemphasized. Most Architects are more concerned with the primary function and aesthetics of their building design, whereas equal attention should be paid to the safety of occupants. This is commonly associated with lack of incorporation of the fire codes in designs, hence making prevention of fire outbreak and rescue of occupants in the case of outbreak, difficult for fire fighters.

This research looks into the existing fire codes for buildings in Nigeria and its incorporation into building design practice, hence comparing those codes and their implementation with other existing codes, hence looking into prescriptive and 'performance based codes. The contrast between the codes and building design practice in Nigeria forms a strong base for this research.
\end{abstract}

Keywords: Design practice, building code, fire code, compartmentation, fire safety, building design, building construction

\section{Introduction}

The prevalence of fire hazards on buildings is currently an issue for all stake holders in the construction industry due to its frequent rate of occurrence. As such, equal considerations should be given to all building types, in order to adapt a system of safety approach for both public and private structures, which will effectively help to salvage the situation. In all building types both the passive and active fire prevention methods should be considered, Barnett .J (2002). All aspects of design such as architectural, structural, electrical and mechanical designs should be given relevance to safety codes and regulations. Haejun. p et al., (2004).

Worthy of note is that the contrast between fire codes and architectural design practice mainly results from inefficient use of the codes by professionals due to (i) Bulkiness of the code (ii) Access to the codes (iii) Ineffectiveness of law enforcement (v) Clients demand and affordability. These have consequently resulted to incessant fire outbreaks on a number of public buildings in Nigeria.

Notwithstanding, the National Building codes have been made available by the federal government of Nigeria, in order to set minimum standards on buildings, pre-design, design, construction, and post construction stages. This was done to ensure safety and proficiency in the building industry, due to incessant collapse of buildings, fire infernos, built environment abuses and other disasters.

However, the prevalence of fire hazards over the years does not justify the effective application of these codes. Some of the infernos experienced on public buildings over the years as gathered by the Nigerian Fire service includes; the Sango plank market Ibadan, the old Bida market in Niger where 600 shops were raised by fire, Ogunpa market fire which occurred January 16th, 2013,premium times,(2013). 
In 2012 as recorded by federal fire service of Nigeria, 56 public buildings were raised by fire, premium times, (2013). Also, as collated by the Federal Fire Service, from January to December 2017, Nigeria recorded the highest number of fire incidents of 160 which includes 99 public buildings/ government quotas. Leadership.ng (2017)

Furthermore, the world has witnessed the loss of many lives in both public and residential buildings as a result of fire outbreak, including the world trade centre (USA) inferno which incurred a property loss amounting to \$22.7 billion. PEPSPP(2009) Mostly public buildings have been affected by these outbreaks, resulting from inadequate implementation of fire codes on building designs and constructions. Hence, several fire preventive initiatives have been introduced around the world in an attempt to curb the prevailing cause of fire occurrence, some of which includes sensitization of the populace on community base programs, education training for students in schools and most importantly, the introduction of building codes and regulations for design and building constructions.

It is on this premise that this research seeks to focus on Nigeria's fire code in relation to its application by professionals.

\section{Fire Codes for Building Designs}

Essentially, fire codes for building designs are a collection of regulations adopted by a city to govern the design and construction of buildings. They are basically classified into two; Passive fire control systems and active fire control systems Barnett, J. (2002).Passive fire control system deals with the aspect of design and construction of buildings which puts into consideration safety applications such as means of egress(escape route), compartmentation, access for fire fighters and materials. Worthy of note is that, compartmentation is key when it comes to passive fire control systems in public or residential buildings because it makes provision for area of refuge for building occupants, thereby making it easy for fire fighters to access and exit the building for easy evacuation of occupants and properties. compartmentation allows for the prevention of vertical spread of fire, e.g. occupants on the next floor or apartment to escape during a fire outbreak. Similarly, the use of compartmentation is very effective when it comes to the horizontal spread of fire. The codes serves as a guide for design application for passive fire control systems. According to the Nigerian National Building Code, (2006), are as follows;

\subsection{Compartmentation}

The National building code states in section 7.1.1.3 the separation of occupants in fire resistive construction, either vertically, horizontally or both.

\subsection{Materials}

"Section 5.3.1.1 of the National building code states that steel, iron, concrete or masonry shall be used as type 1 fire resistive building material".

\subsection{Means of Egress}

Means of egress are to be provided in every fire resistant structure leading to an open space whose access is directly to a street ( section 7.3.3.1)

Active fire control system on the other hand has to do with the post design stage which includes the use of sprinklers, smoke and fire detectors, fire extinguishers and fire alarms. It is considered as a means of fire suppression and can function either manually orautomatically. Manual means of fire control depends on humans in order to function while automatic means of fire control are programmed to operate by themselves as soon as there is a fire incident. For active fire control, the National building code states as follows;

\subsection{Sprinkler Systems}

Sprinkler systems are also to be provided in every fire resistant building, designed and provided for every floor constituting a water floor device and shut off valves. (section 5.3.7.2)

\subsection{Smoke Control}

Section 5.21 states that an air system which is mechanically operated to emit air, must be installed, and the opening of the exhaust located in a smoke trap area of an atrium.

\subsection{Alarms} buildings.

Section5.3.7.10 states that fire alarms with communication systems must be installed in every floor of all tall

\section{Performance and Prescriptive Based Codes}

A performance code requires that a building as a whole performs to a certain standard, whereas a prescriptive code requires that each component is built to a certain standard. Most countries make use of "performance base" codes. This is because performance based codes are considered more effective and flexible in terms of application. H.Z Vischer, (2003). The nature of the code makes it possible for professionals to have an advantage of individual cognition which may influence the cost of construction of a given design and adoption of change in technology.

However, the Nigerian National building code is prescriptive. Hence codes for fire and other aspects of building are not quite flexible. For example, areas of refuge otherwise known as compartmentation are recommended for design in 
the National building code. This can serve as alternate to the automatic sprinkler system". Section 5.3.7.10, National Building Code, (2006).

But such compartmentations must conform to the following, as stated in section 5.3.7 of the National building code:

- Each storey may be divided into more than one areas of same size and non-should exceed $139 \mathrm{~m} 2$.

- Each compartmentation shall be constructed with one lift, leading to the main floor and a minimum of one enclosed stairway at the exits.

- Flame barriers are recommended on floors that are vertically adjacent to one another at exterior walls of within $1.5 \mathrm{~m}$ horizontally.

- Such walls above are required to have a fire resistance rating of two hours minimum. Such walls are to be caulked with non-combustible and impervious materials.

The code emphasizes on complete separation of occupants in fire resistive construction. A performance based code is otherwise flexible for design cognition and makes room for easy adoption of change in technology by professionals.

\section{Compliance to Building Fire Codes}

The contrast between the code and design practice mostly results from non-adherence of the codes by professionals. Sometimes the designs are made complex such that functional flow is not easily understood by the occupants, especially in the case of public buildings where the occupants do not dwell. For example, in shopping malls where the activities, basically have to do with buyers who only come once in a while to make purchases. Complex floor plan that does not adequately explain itself will make it difficult for occupants to easily exit the building in the case of fire outbreak, or for fire fighters to identify access for prompt evacuation of occupants O’ Neill, (1991).

However, the ineffective implementation of building/ fire codes could lead to building collapse, Inadequate planning of towns and cities, use of substandard products and untested materials and lack of hazard considerations in design process by professionals.

These codes are aimed at achieving standards in building construction from design stage to post construction stage, in order to ensure safety in the Nigerian construction industry. Hence the inadequate implementation could also lead to poor Standard Specification (SS) as ascertained by the findings of Florunso and Ahmed, (2013). The noncompliance to SS in Nigeria has resulted to frequent replacement of materials, high cost of maintenance, poor performance of building components among others.

Similarly, Shingo, (1988) and Abdusallam et, al.(2014) stated that non compliance to SS has resulted to waste of materials, time, resources and poor execution of construction works. It is to this effect that there is need to pay more attention to the existence and implementation of the Nigerian National building code in design and construction which will consequently address the issues surrounding standard specifications and quality control in the building industry Kabiru, (2018).Essentially this could go a long way in reducing fire hazards.

\section{Conclusion and Recommendation}

Fire codes for buildings are meant to help professionals in the construction industry to ensure a safety compliant design and construction of buildings which puts into consideration, the available fire prevention systems which are mainly passive or active. These two systems of fire prevention and control are adequately captured in the National building code of Nigeria. This study therefore, identifies the following as factors impeding the application of these codes which has lead to incessant fire outbreak in the country:

- Inadequate law enforcement

- Cost implication

- Clients demand and affordability

- Lack of fire safety culture in Nigeria

- Bulkiness of the code (mixed with the Nigerian building code)

- The codes are prescriptive in nature

The general conclusion of this research reveals that there is a contrast between professionals and architectural design practice for fire codes and application. However, the need for Architects to pay more attention to fire codes and application is necessary. Awareness of the existence and application of the codes should be raised by the help of training session from architectural schools and other related fields especially.

Also, the need to adopt a performance based code is necessary due to the adverse change in technology as this will give professionals an ample opportunity to proffer solutions based on their own design cognition which would conform to change in technology and make room for cost control in order to meet clients demand.

The table below shows the advantage of performance based code over prescriptive based code. 


\begin{tabular}{|c|c|}
\hline Performance Based Codes & Prescriptive Based Codes \\
\hline Quite flexible for design cognition & Rigid in nature \\
\hline $\begin{array}{l}2 \text { Can easily blend with the international } \\
\text { code because the international code is also } \\
\text { prescriptive in nature. }\end{array}$ & In contrast with the international codes \\
\hline $3 \quad$ Cost effectiveness & Quite expensive \\
\hline $\begin{array}{l}4 \quad \text { Makes room for change in technology for } \\
\text { fire safety. }\end{array}$ & $\begin{array}{l}\text { 4. Prescriptive fire may be in contrast with } \\
\text { new technology }\end{array}$ \\
\hline $\begin{array}{l}5 \text { In performance based codes fire safety } \\
\text { objectives are stated clearly hence, architects and } \\
\text { engineers are free to device their own means of } \\
\text { attaining fire safety objectives }\end{array}$ & $\begin{array}{l}5 . \quad \text { There are restrictions to how much a } \\
\text { designer can contribute in terms of cognition. }\end{array}$ \\
\hline
\end{tabular}

Table 1

The need for having fire codes and regulations separate from the national code is highly essential, as it will help reduce the need for Architects to read through the whole national codes trying to find the sections for fire safety, hence making the design process more tedious and tasking. Furthermore, the need for periodic review of the constitution is also necessary as there is always an improvement in technology. The periodic review of the codes will help in making better provision for safety, in line with change in technology.

Finally, existence of codes without enforcement will definitely nullify the effectiveness of the codes. The need for adequate enforcement of fire codes is highly essential at both federal and state levels as this would help to achievea fire safe design of buildings for occupants through checking and making approvals of drawings based on safety conditions and ensuring periodic inspection of fire fighting equipments and installations. Also, the Nigerian fire codes are mostly prescriptive in nature. Hence a performance based code may be more ideal in order not to restrict architects and other professionals in the construction industry from making research and implementation in the area of fire safety.

\section{References}

i. Arthur, E., Casey, C., ve Grant, C. (2002) Codes and Standards for the Built Environment Engineer NFPA Standards Council.

ii. ASTM. (2007). "Standard test methods for fire tests of building construction and materials." ASTM E119, West Conshohocken, PA

iii. ASTM (2012) Standard Test Method for Surface Burning Characteristics of Building Materials(ASTM E84 - 12a), ASTM International, West Conshohocken, PA

iv. Ayanz , J., Moreno, J., ve., Andrea, C. (2013) Analysis of large fires in European Mediterranean landscapes: Lessons learned And perspectives Department of Environmental Sciences, University of Castilla-La Mancha, Toledo, Spain

v. Baade, H.(2002) The Legal Effects of Codes of Conduct for Multinational Enterprises, in: N.Horn (ed.), Legal Problems of Codes of Conduct for Multinational Enterprises, Deventer et al. (1980), 3-43.

vi. Babrauskas, V., Lucas, D., Eisenberg, D. ve Singla,V. (2012) Flame retardants in Building insulation: a case for re-evaluating building codes. Department of Chemistry, University of California, Berkeley, CA 94720, US

vii. Barnett, J. (2002) World Trade Center Building Performance Study: Data Collection, Preliminary Observations, and Recommendations. Federal Emergency Management Agency Region II. New York, NY.

viii. Beyhan, F., Lakot, E., ve Alemdag (2014)Fire Safety In Atrial Constructions And Effects Of Architectural Decisions International Journal Of Academic Research 1Gazi University, Faculty of Architecture, Ankara Karadeniz Technical University, Faculty of Architecture, Trabzon (TURKEY).

ix. Bosch, J., van, .G., ve Jansen, J.(2006)Design Decisions: The Bridge between Rationale and Architecture Rationale Management in Software Engineering SBN 978-3-540-30997-0I Bisby, L. A. (2003). "Fire Behavior Of Fibre-Reinforced Polymer (FRP) Reinforced Or Confined Concrete." Ph.D. Thesis, Queen's Univ., Kingston, ON, Canada

x. Brown, B.A. (1995) A model emergency response plan. Professional Safety, January, 24-27. Bukowski, R. ve Babrauskas, V. (1994 "Developing Rational, Performance-based Fire Safety Requirements in Model Building Codes," Fire and Materials: An International Journal, Vol. 18,No. 3, , pp. 173-192

xi. British Standard Institution. (1987). "Fire tests on building materials and structures Part 20: Method from determination of the fire resistance of elements of construction (general principles)." BS476-20, London

xii. Chen, G.C. (2008) Synthesis And Evaluation Of Phosphortriamidates In Wood For Thermal And Fungal Decay Protection. Holzforschung 62:318-321.

xiii. Chow, K. (2003). "Fire safety in green or sustainable buildings: Application of the fire engineering approach in Hong Kong", Architectural Science Review, Vol. 46, No. 3, pp. 297-303

xiv. Chow W. (2007) Fire Safety Provisions For Super tall Buildings. International Journal on Architectural Science, Volume 7, Number 2, p.57-60, 2006 Corneo, E., Gallina, G., ve Mutani, G., (1997) "Fire Safety in a Historical Building: A Case History," Proceedings of Symposium for '97 FORUM, Applications of Fire Safety Engineering, Tianjin, China, 1997, pp. 60-72. 
xv. David, E. (1978). Concepts in Building fire safety: New York, John Wiley and sons. David, N.,(2008) Fire and Concrete Structures. Engineered Structures, Portland Cement Association 5420 Donald, W. et al (1999). Time saver standards for architectural design data: USA, McGraw-hill companies.

xvi. Douglas, L. (1980). Regional shopping centre: Time saver standards for building types. Dean, H. (2004). Passive and active environmental controls "informing the schematic designing of buildings" New York, McGraw-hill.

xvii. Evans, D., (1988) "Ceiling Jet Flows", the SFPE Handbook of Fire Protection Engineering, Section 1, Chapter 9, National Fire Protection Association, First Edition

xviii. Federal Republic Of Nigeria (2005) National Building Code ISBN 0409023612 H Ministry of Housing and Urban Development Abuja Florunso \& Ahmed (2013) Parameters for building Materials Specifications in Lagos, Nigeria

xix. Garston, W. (1988) Rules for the construction and installation of firebreak doors and shutters. LPC, available from LPC, BRE, Bucknalls Lane, Herts, WD25 9XX, CUK)

xx. Goodfellow, T., (2013) Planning and development regulation amid rapid urban growth: Explaining divergent trajectories in Africa Department of Town and Regional Planning, University of Sheffield, Western Bank, Sheffield S10 2TN, United Kingdom

xxi. Grant, G., Brenton, J., ve Drysdale, D. (2000) "Fire Suppression by Water Sprays", Progress in Energy and Combustion Science, Vol 26, pp. 79-130

xxii. Gregory, K. ve Shino, P. (2014) Balancing active and passive fire protection JBA Consulting Engineers, Las Vegas

xxiii. Gross, J. (1990) "Harmonization of Standards and Regulations: Problems and Opportunities for the United States," Building Standards, National Institute of Standards and Technologies, Gaithersburg, MD, pp. 32-35.

xxiv. Haejun, P., Brian, J., Meachama, A., ve Mark, G. (2014) Integration of fire safety and building design Protection Building Research \&Information, Engineering,

xxv. Worcester Polytechnic Institute, 100 Institute Road, Worcester, MA 01609, US Hisashi, M, ve Yoshiyuki, F. (2012) Fire resistance of wood treated with various ionic liquids (ILs) Holzforschung 67(7): 787-793

xxvi. Isner, M. (1986.) High-Rise Office Building Fire Alexis Nihon Plaza, Montreal, Canada, October 26, 1986. Quincy, MA: National Fire Protection Association

xxvii. Keller, H. (2005) Corporate Codes of Conduct and their Implementation. The Question of Legitimacy

xxviii. Kodur, V. K. (2013) Evaluating the Fire Response of Concrete Beams Strengthened with Near-Surface-Mounted FRP Reinforcement Journal of Composites for Construction @ A Asce / July/ August 2013 / 517

xxix. Krishnan, G., Gakkar, R.., Prakash, S., (1991) “Water Droplet Evaporation in Fire Plumes”, ICLASS-91 Proceedings, National Institute of Standards and Technology, Gaithersburg, MD, pp. 97-104.

xxx. Lawrence, W. (2003) Fire compartmentation and fire risk management McGuire, J.H. (1962) Fire and The Compartmentation of Buildings. Building Digest, Division of Building Research National Council Canada

xxxi. Merritt, F. and Ricketts, J. (2001). Building design and construction handbook, sixth edition: McGraw-Hill Inc.

xxxii. Michael G. (2004)Fire Protection of Structural Steel in High-Rise Buildings. U.S. Department of Commerce Technology Administration National Institute of Standards and Technology NIST GCR 04-872

xxxiii. Miyafuji, H. ve Fujiwara, Y. (2014). Fire resistance of wood treated with various ionicliquids (ILs)

xxxiv. Mohammad, S., Al-Homoud, A., ve MousaM.K (2004) Safety design practices in Residential buildings in Saudi Arabia 1Department of Architectural Engineering, King Fahd University of Petroleum and Minerals, Dhahran 31261, Saudi Arabia

xxxv. O'Neill, M. J. (1991). Effects of Signage and Floor Plan Configuration on Way Finding Accuracy. Environment and Behavior, 23(5), 553-574.Palmieri, A., Matthys, S., ve and Taerwe, L. (2011). "Influence of high temperature on bond between NSM FRP bars/strips and concrete," Proc. 10th Int. Symp. of the Fiber-Reinforced Polymer Reinforcement for Reinforced Concrete Structures, American Concrete Institute, Farmington Hills, MI, 919-930

xxxvi. Park, S., ve., Berks A, (2002) Fire protection for structural steel in buildings (third Edition P013) ISBN 1870409205 ASFPCM/ SCI/ FTSG UKPeace Economics, Peace Science and Public Policy (volume 15, issues) The Economic

xxxvii. Impact of September11, 2001, Terrorist Attacks. (2009) Premium times (2013), retrieved from https/ / www.premiumtimessng.com 25 th April 2019

xxxviii. Quincy, MA. (1999). "NFPA 13, Standard for the Installation of Sprinkler Systems", National Fire Protection Association, Regulatory Reforms (fire safety) order (2005). Educational Premises Guidance issued by HM Government. Fire safety Technical Guide.

xxxix. Rodrigo, M., (2009) An analysis of the fire safety codes in Brazil: Is the performance- based approach the best practice? Fire Safety Journal 44 749-755 OPTSEG- Optimal Safety Engineering, Research Department, NW13RE, London, UK

xl. Richardson, L. R., (1994) "Determining Degrees of Combustibility of Building Materials- National Building Code of Canada," Fire andMaterials: An International Journal, Vol. 18, No. 2, 1994, pp. 99-106.

xli. Seddon, K.R. (1997) Ionic liquids for clean technology. J. Chem.Technol. Biotechnol. 68:351-356.

xlii. Sheppard, D.T (2002) Spray Characteristics of Fire SprinklersNIST GCR 02-838

xliii. Shino, G. (2004) Balancing active and passive fire protection. Consulting Engineers, Las Vegas vol.51 issue 9, p2834.71

xliv. Silwood, P., ve Ascot, Fire protection for structural steel in buildings (third edition P013) ISBN 1870409205 ASFPCM/ SCI/ FTSG (available from ASFP, Association House, 99 West Street, Farnham, Surrey, GU9 7EN, UK

xlv. Siu-Ming, L., Min, L., ve Chun-Mei, Z. (2008) A study on the effect of project Coordinators knowledge on the use of performance-based fire safety Engineering design in buildings. Journal of Building Appraisal4, 15 
xlvi. Strauss, A., \& Corbin, J. (1990). Basics of qualitative research: Grounded theory procedures and techniques. Newbury Park, CA: Sage Publications, Inc.

xlvii. Tashakkori, A., ve Teddlie, C. (2003). Handbook of mixed methods in social and behavioural research. Thousand Oaks, CA: Sage Publications, Inc. - 22. doi: 10.1057/ jba.2008.11

xlviii. Uniform Building Code (1997) Uniform Building Code, vol. 1, Los Angles, International Conference of Building Officials

xlix. Visscher, H., ve Meijer F. (2003) Buildings Regulations on Fire Safety in Europe Proceedings of the CIB-CTBUH International Conference on Tall Buildings, Malaysia School of Architecture and Building Engineering, University of Liverpool, England

l. Wendt, B., Prahl, ve Joseph, M., (1986) "Discharge Distribution for an Axisymmetric Model of a Fire Sprinkler Head", National Bureau of Standards, Gaithersburg, M NBS-GCR-86-517 